\title{
Silica bodies and their systematic implications at the subfamily level in Podostemaceae
}

\author{
Corpos silicosos e suas implicações sistemáticas em nível de subfamília em Podostemaceae
}

\author{
Filipe Gomes Cardoso Machado da Costa ${ }^{1}$, Claudia Petean Bove ${ }^{1}$, \\ Rosani do Carmo Oliveira Arruda ${ }^{2} \&$ C. Thomas Philbrick ${ }^{3}$
}

\begin{abstract}
Podostemaceae is a family of eudicotyledonous rheophytes with unique morphology, sometimes resembling algae, lichens or bryophytes. This study evaluates the taxonomic value of silica-body morphology (presence, location, size, shape, ornamentation) in species representing the three subfamilies: Tristicha trifaria (Bory ex Willd.) Spreng. (Tristichoideae), Weddellina squamulosa Tul. (Weddellinoideae) and Diamantina lombardii Novelo, C.T.Philbrick \& Irgang (Podostemoideae). T. trifaria and D. lombardii have silica bodies in stems and leaves. In contrast, $W$. squamulosa exhibits silica bodies only in the scale-like leaves. The morphology of these bodies is unique to each species. The results denote the taxonomic usefulness of silica characteristics and a need for a more complete study of silica bodies throughout the family.

Key words: aquatic plants, Podostemaceae, silica bodies.

\section{Resumo}

Podostemaceae é uma família eudicotiledônea reófita de morfologia peculiar, lembrando por vezes algas, liquens ou briófitas. O presente estudo avalia o valor taxonômico da morfologia dos corpos silicosos (presença, localização, tamanho, forma e ornamentação) em espécies representantes das três subfamílias: Tristicha trifaria (Bory ex Willd.) Spreng. (Tristichoideae), Weddellina squamulosa Tul. (Weddellinoideae) e Diamantina lombardii Novelo, C.T.Philbrick \& Irgang (Podostemoideae). T. trifaria e D. lombardii apresentam corpos silicosos nos caules e nas folhas, enquanto $W$. squamulosa possui estas estruturas restritas às folhas escamiformes. A diversidade morfológica dos corpos silicosos, específica para cada espécie aqui estudada, comprova o potencial taxonômico deste caráter, até então negligenciado, e aponta para a necessidade de estudos mais abrangentes para essas estruturas em Podostemaceae.
\end{abstract}

Palavras-chave: corpos silicosos, plantas aquáticas, Podostemaceae.

\section{Introduction}

Podostemaceae Rich. ex Kunth is a eudicotyledonous family comprising approximately 50 genera and 300 species. These plants grow in rapidly flowing water, attached to rocks or other solid substrate. Species occur in the tropics with a few species reaching temperate regions (Cook \& Rutishauser 2007). The family is divided into three subfamilies (Engler 1930; Kita \& Kato 2001). Tristichoideae (three genera), which is sister to the rest of the Podostemaceae, is represented by a single species (Tristicha trifaria (Bory ex Willd.) Spreng.) in the neotropics. The monotypic Weddellinoideae is endemic to the neotropics. The largest (47 genera) and most widespread subfamily is Podostemoideae, which occurs in both paleo- and neotropics (Ruhfel et al. 2011).

Many authors have reported on the unusual vegetative body of Podostemaceae. For example, Rutishauser (1997) and Rutishauser et al. (2008) have discussed the difficulty of applying the classical root-stem-leaf model to these plants. The unusual morphology of riverweeds is linked to their environment, although specific cause-effect relationships remain unclear (e.g. Pfeifer et al. 2009).

Podostemaceae are also notable in terms of their anatomy. Plants are characterized by the lack of aerenchyma (otherwise common in

\footnotetext{
'Universidade Federal do Rio de Janeiro, Depto. Botânica, Museu Nacional, Quinta da Boa Vista, Rio de Janeiro, 20940-040, Brazil. ${ }^{2}$ Universidade Federal do Mato Grosso do Sul, Depto. Biologia, Av. Senador Felinto Muller, Mato Grosso do Sul, 70070-900, Brazil. ${ }^{3}$ Western Connecticut State University, Department of Biological and Environmental Sciences, Danbury, Connecticut, 06810, U.S.A Author for correspondence: cpbove@hotmail.com
} 
aquatic plants), lack of stomata, lack of an endodermis and pericycle, inconspicuous vascular tissue, faint distinction between xylem and phloem, abundant starch grains, presence of laticiferous and/or secretory channels and presence of silica bodies (e.g.Schnell 1967, Cusset \& Cusset 1988, Cook \& Rutishauser 2007). Although the presence of silica bodies in Podostemaceae has been noted by numerous authors in many genera, such as Apinagia, Diamantina, Podostemum and Weddellina (e.g. Schnell 1967, Rutishauser et al. 2005, Koi \& Kato 2007), morphological descriptions and comparative studies involving taxonomic or phylogenetic perspectives are lacking.

Plants take up silicon ( $\mathrm{Si}$ ) as silicic acid ( $\mathrm{Si}$ $\left.(\mathrm{OH})_{4}\right)$ and accumulate it as hydrated silica $\left(\mathrm{SiO}_{2} \cdot \mathrm{nH}_{2} \mathrm{O}\right)$ in the cytoplasm (Currie \& Perry 2007), vacuoles or cell walls of roots, stems and leaves, or reproductive structures (Kealhofer \& Piperno 1998; Neethirajan et al. 2009). Silica particles can be present in roots in many shapes, such as spherical, dumb-bells, saddles, bowls, and boats (Cooke $\&$ Leishman 2010). These patterns, as well as metric data, have been used as important taxonomic characteristics, even at the infrageneric level, in monocots, like Poaceae, Zingiberaceae, and Orchidaceae, as well as in Pteridophyta (e.g. Pteridaceae) (Kealhofer \& Piperno 1998; Prychid et al. 2003; Sundae 2009). In Podostemaceae the silica can be found occupying the cytoplasm or only in the vacuoles (Jäger-Zürn 2011). Although the presence of silica bodies is well documented in Podostemaceae, they have been poorly investigated in terms of morphology and not utilized taxonomically. Moreover, recent phylogenetic studies of neotropical Podostemaceae (Tippery et al. 2011) reveal a lack of apparent morphological synapomorphies for some major clades. Clearly further examination of morphological features of neotropical Podostemaceae is needed.

The aim of this study was to evaluate the potential application of silica bodies in the taxonomy of neotropical Podostemaceae at the subfamily level. In this sense, the presence, location and morphology of the silica bodies were determined for three representative species, one from each of three subfamilies. Tristichoideae, which is largely paleotropical, was represented by Tristicha trifaria (Bory ex Willd.) Spreng. Weddellina squamulosa Tul. was included as the sole member of subfamily Weddellinoideae. Podostemoideae, the largest subfamily, was represented by Diamantina lombardii Novelo, C.T. Philbrick \& Irgang, the most basal member of this subfamily (Ruhfel et al. 2011).

\section{Material and Methods}

Mature plants were fixed in $\mathrm{FAA}_{70}$ (Johansen 1940) and preserved in 70\% ethanol. Longitudinal and transversal hand-cut sections were cleared in $50 \%$ commercial sodium hypochlorite solution and rinsed in $1 \%$ acetic acid and distilled water. Samples were then stained with alcian blue and fuchsin $0.1 \%$ (Luque et al. 1996). A portion of the fixed samples were dehydrated in an ethanol series, subjected to pre-infiltration and subsequently infiltrated in hydroxy methacrylate resin following standard procedures. Transverse and longitudinal sections ( $5 \mu \mathrm{m}$ thick) were made using a rotary microtome.

Sections were stained with $0.05 \%$ toluidine blue at $\mathrm{pH} 4.7$ (O'Brien et al. 1965). Histochemical tests were performed on freehand-sections to detect starch, using Lugol's solution, and clove oil and heated phenol to detect silica bodies (Johansen 1940). For morphological studies of silica bodies in light microscopy, fragments of vegetative material were softened in a solution proposed by Franklin (1945), soaked with clove oil and stained with phenol. All samples were mounted in 50\% glycerin on slides with cover slips. Observations were carried out with an Olympus ${ }^{\circledR}$ (CX-31) light microscope. To observe the shape and ornamentation of silica bodies with scanning electron microscopy, fragments of specimens were carbonized in a muffle furnace for $6 \mathrm{hr}$ at $600^{\circ} \mathrm{C}$, soaked with $70 \%$ ethyl alcohol (Wattiez \& Sternon 1942), and transferred to aluminum stubs. Stubs were sputter coated with gold platinum (Denton Vacuum Desk IV) and examined using a Jeol JSM $6390 \mathrm{LV}$ scanning electron microscope.

In size descriptions, the lower and upper ranges were listed parenthetically. Arithmetic mean and standard deviation values were based on 20 measurements of one specimen of each species. At least one more voucher of each species was analyzed and 10 measurements were taken for comparison. Selected specimens for morphometric data shown in Table 1 are indicated by an asterisk (*) in the list of material. Studied specimens are housed at the Herbarium of the Museu Nacional, Universidade Federal do Rio de Janeiro (R) and 
listed as follows: Diamantina lombardii - C.P. Bove et al. 2131 *; C.P. Bove et al. 2253. Tristicha trifaria - C.P.Bove et al. 1867*; C.P. Bove et al. 1736. Weddellina squamulosa - C.P. Bove et al. 1862 *; N.B. Barros Filho 210976.

\section{Results and Discussion}

This study confirmed the presence of starch grains in parenchyma cells and silica bodies occupying the cell cytoplasm in each of the species examined. The morphology (shape and ornamentation) of the silica bodies was different in each species analyzed. In Tristicha trifaria they were rectangular with many crests oriented perpendicular to the main axis (Fig. 1a-b). Mean length and width were $62.4 \mu \mathrm{m}$ and $17.6 \mu \mathrm{m}$, respectively (Tab.1). In Weddellina squamulosa the silica bodies were triangular, ellipsoidal, ovate or oblong, with many rounded depressions and projections distributed somewhat uniformly along the surface (Fig. 1c-d). Average size was $44.1 \mu \mathrm{m}$ in the longest dimension (Tab.1). Lastly, in Diamantina lombardii the silica bodies were rectangular or oblong with many holes of variable diameter (Fig. 1e-f). These holes were distributed only on the surface of the body oriented to the exterior of the plant (Fig. 2e). Average length and width were $32 \mu \mathrm{m}$ and $16.6 \mu \mathrm{m}$, respectively (Tab.1). Thecomparison specimens analyzed showed uniformity of morphological and morphometric data.

In Podostemaceae, the aggregation of silica bodies in peripheral tissues can be referred to as forming a "carapace," which may provide protection against mechanical damage and drought stress
(Metcalfe \& Chalk 1979). Our results indicated that Tristicha trifaria (Fig. 2a) and Diamantina lombardii (Fig. 2b) have silica bodies in epidermal and in some hypodermal cells of stem and leaves. In contrast, Rutishauser et al. (2005) reported that silica bodies occur in only a few epidermal and hypodermal cells in stem and leaves of $D$. lombardii; a difference that may have been induced by methodological bias. The silica bodies forming a carapace were present here in sections made with a Ranvier microtome. In contrast, sections made with a rotary microtome showed fewer silica bodies in all specimens. Methodological bias provided by rotary microtome (thinner sections) causes removal of the silica bodies in tissues (Fig.2d).

In Weddellina squamulosa these structures were present only in the epidermis of the scale-like leaves (Fig. 2c), corroborating the report of Koi \& Kato (2007). Interestingly, this species is often used as fish-bait (C.P. Bove, personal communication). Consequently, if silica bodies serve an antiherbivory function, it likely relates to non-fish herbivores (e.g. invertebrates). It is also notable that leaves of Podostemaceae are present in stomach content analyses of fish species (e.g. Astyanax, Characidae) indicating it as a potential food source (Villela et al. 2002).

The ornamentation and shape of the silica bodies were notably different among the subfamilies investigated. Moreover, whether such variation is useful at lower taxonomic levels (e.g. among genera or species) remains to be determined as more species are analyzed. The potential applicability of silica body morphology and

Table 1 - Shape, ornamentation, occurrence and size of silica bodies from three species of Podostemaceae, one representing each subfamily. Data are mean \pm standard deviation; minimum and maximum values in parentheses $(\mathrm{n}=20)$.

\begin{tabular}{|c|c|c|c|}
\hline & $\begin{array}{c}\text { Tristicha trifaria } \\
\text { (Tristichoideae) }\end{array}$ & $\begin{array}{l}\text { Weddellina squamulosa } \\
\text { (Weddellinoideae) }\end{array}$ & $\begin{array}{c}\text { Diamantina lombardii } \\
\text { (Podostemoideae) }\end{array}$ \\
\hline Shape & Rectangular & $\begin{array}{l}\text { Triangular, ellipsoidal, } \\
\text { ovate or oblong }\end{array}$ & Rectangular or oblong \\
\hline Ornamentation & $\begin{array}{l}\text { Crests perpendicular } \\
\text { to longitudinal axis }\end{array}$ & $\begin{array}{l}\text { Rounded depressions, } \\
\text { projections on surface }\end{array}$ & $\begin{array}{l}\text { Holes of variable diameter } \\
\text { on upper side }\end{array}$ \\
\hline Occurrence & $\begin{array}{l}\text { Epidermal and hypodermal } \\
\text { cells of stem and leaves }\end{array}$ & $\begin{array}{l}\text { Epidermal cells of } \\
\text { scale-like leaves }\end{array}$ & $\begin{array}{l}\text { Epidermal and hypodermal } \\
\text { cells of stem and leaves }\end{array}$ \\
\hline Length $(\mu \mathrm{m})$ & $\begin{array}{l}62.4 \pm 15.1 \\
(38.5-87.7)\end{array}$ & $\begin{array}{c}44.1 \pm 3.9 \\
(38.0-52.0)\end{array}$ & $\begin{array}{c}32.0 \pm 7.4 \\
(22.5-47.2)\end{array}$ \\
\hline Width $(\mu \mathrm{m})$ & $\begin{array}{c}17.6 \pm 4.2 \\
(10.5-26.5)\end{array}$ & $\begin{array}{c}22.6 \pm 3.4 \\
(16.8-28.4)\end{array}$ & $\begin{array}{c}16.6 \pm 2.2 \\
(12.2-20.2)\end{array}$ \\
\hline
\end{tabular}



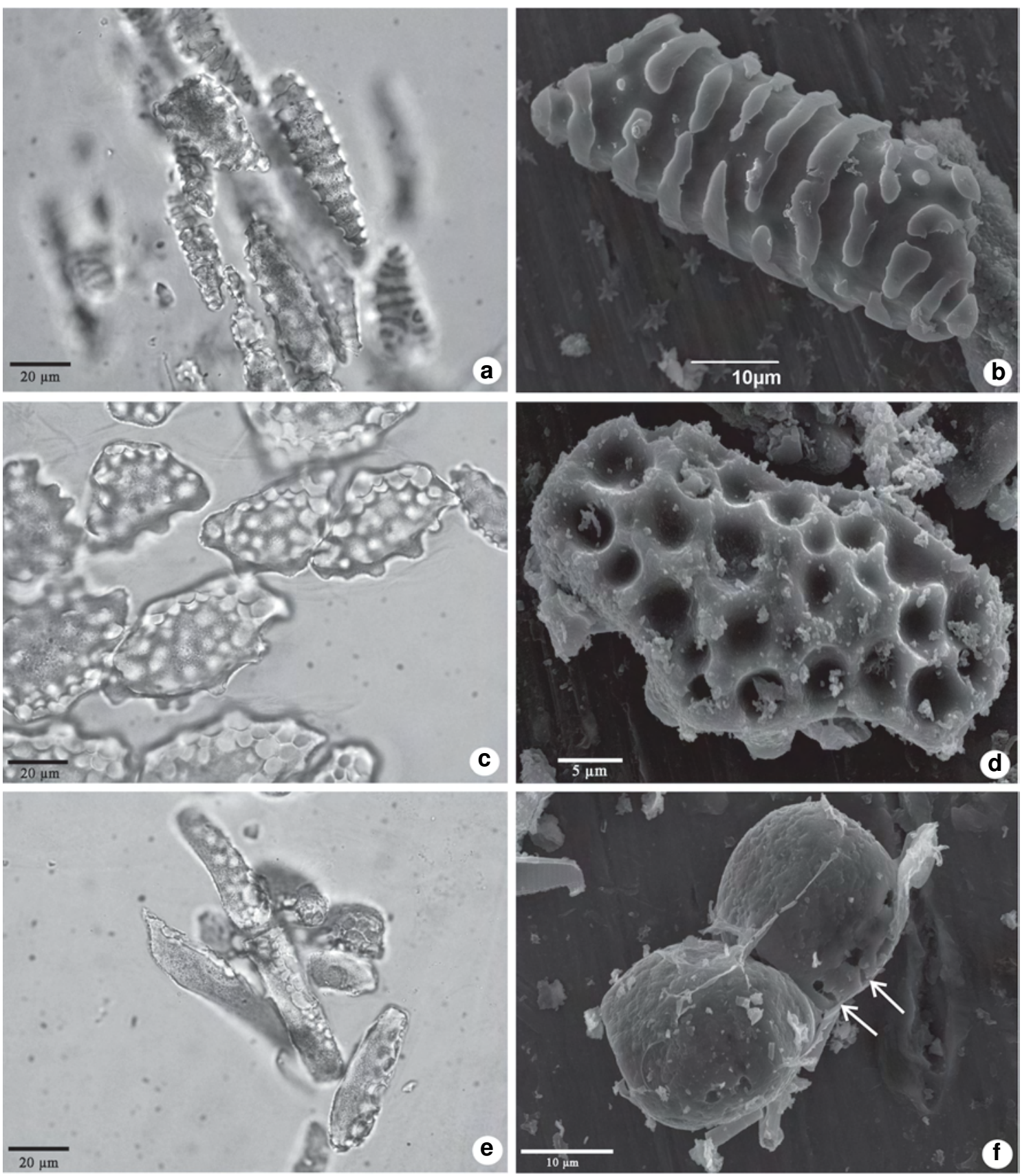

Figure 1 - a-b. Isolated silica bodies of Tristicha trifaria - a. rectangular silica bodies on light microscopy; b. silica body surface with crests perpendicular to main axis on scanning electron microscopy. c-d. Isolated silica bodies of Weddellina squamulosa - c. triangular, ellipsoidal, ovate and oblong silica bodies on light microscopy; d. silica body surface with circular depressions on scanning electron microscopy. e-f. Isolated silica bodies of Diamantina lombardii e. rectangular and oblong silica bodies on light microscopy; f. silica body surface with holes of irregular form (arrows) on scanning electron microscopy. 


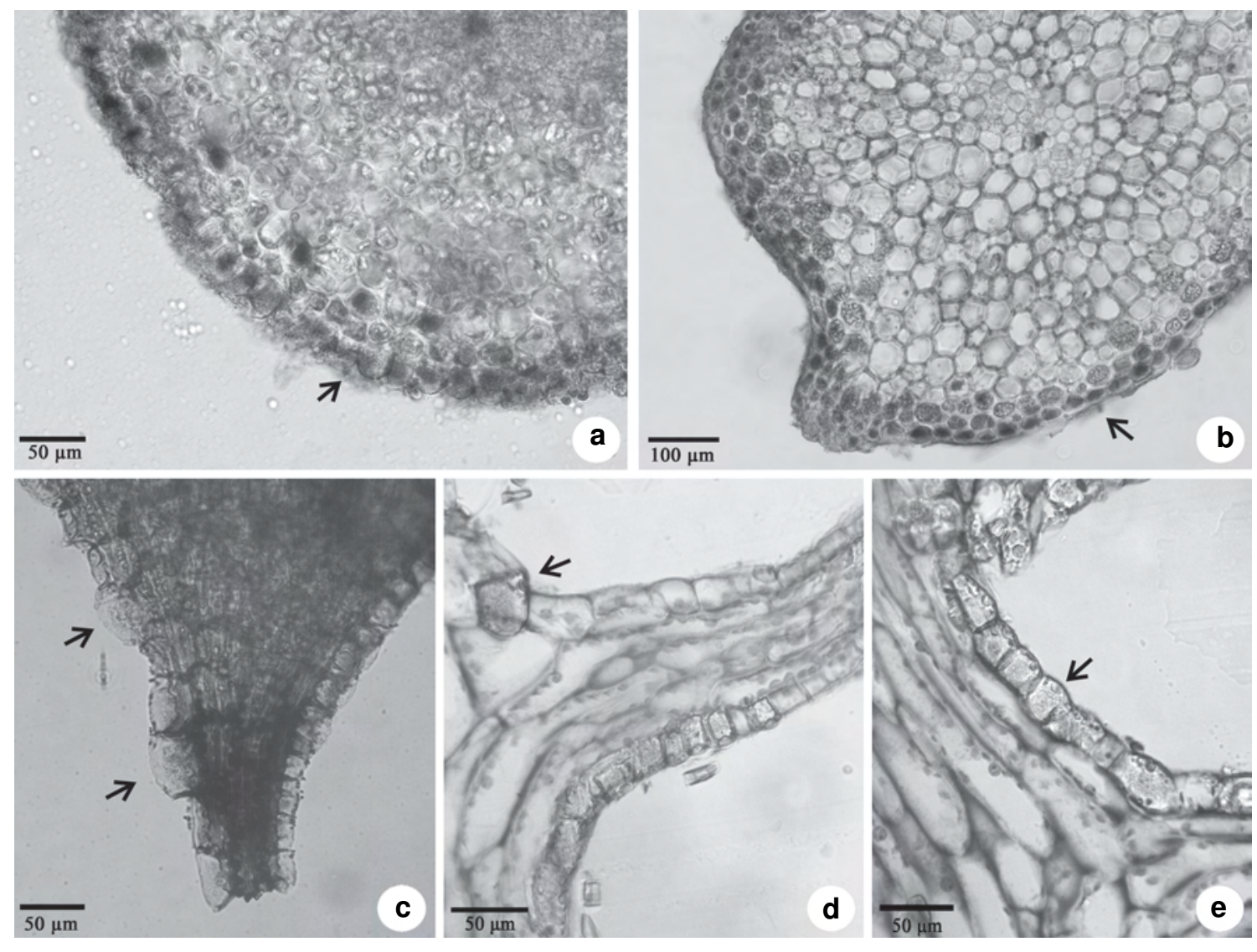

Figure 2 - a-e. Transversal (a-c) and longitudinal (d-e) sections of the vegetative body on light microscopy. a. Tristicha trifaria. Arrow shows a group of silica bodies (dark content) in epidermal cells of stem forming a "carapace. b. Section made with Ranvier microtome of Diamantina lombardii. Arrow shows many silica bodies (dark content) in epidermal cells. c. Weddellina squamulosa. Arrows shows silica bodies in epidermal cells of scale-like leaf attached to stem. d. Section made with rotary microtome of $D$. lombardii. Arrow shows a removed silica body from epidermal cell. e. $D$. lombardii. Arrow showing a silica body with the holes oriented toward the external surface of plant.

occurrence in Podostemaceae to systematic purposes, based on broad taxonomic and phylogenetic sampling, is presently underway.

Due to the high capacity of fossilization, the morphology of silica bodies can also be applied to paleobotanical/paleoecological examination (see "opal phytoliths" in Alexandre et al. 1997). It is notable that silica bodies may not migrate through strata to the same extent as do other microfossils, such as pollen grains and diatoms (Prychid et al. 2003). Perhaps better understanding of the form and diversity of silica bodies in Podostemaceae can contribute to new insights into the history of these fascinating plants, for which a fossil record is largely absent, and help on the reconstruction of ancient aquatic ecosystems.

\section{Acknowledgments}

We are grateful to Dr. Lygia Fernandes, Dr. Bárbara Hayad and the staff of the Anatomy Laboratory. of the National Museum (UFRJ) for the laboratory facilities where part of this study was done. This work was supported by Conselho Nacional de Desenvolvimento Científico e Tecnológico Ministério de Ciência e Tecnologia (CNPq-MCT) through fellowship to F.G.C.M.C.; Research Production Grant (2009-2011: proc. 307073/2008-4 to C.P.B.); PROTAX an REFLORA Projects (proc. 562251/2010-3 and 563534/2010-9 to C.P.B.) and National Science Foundation Grant DEB-0444589 and Connecticut State University-AAUP research grants to C.T.P. We thank the herbarium staff of the Museu Nacional (R) for allowing the study of their specimen. 


\section{References}

Alexandre, A.; Meunier, J.D.; Lézine, A.M.; Vincens, A. \& Schwartz, D. 1997. Phytoliths: indicators of grassland dynamics during the late Holocene in intertropical Africa. Paleogeography, Paleoclimatology, Paleoecology 136: 213-229.

Cook, C.D.K. \& Rutishauser, R. 2007. Podostemaceae. In: Kubitzki, K. (ed.). The families and genera of vascular plants. Vol. 9. Springer, Berlin. Pp. 304-344.

Cooke, J. \& Leishman, M.R. 2011. Is plant ecology more silicious than we realize? Trends in Plant Science 16: 61-68.

Currie, H.A. \& Perry, C.C. 2007. Silica in plants : biological, biochemical and chemical studies. Annals of Botany 100: 1383-1389.

Cusset, G. \& Cusset, C. 1988. Étude sur les Podostemales: 10. Structures florales et vegetatives des Tristichaceae. Bulletin du Muséum National d'Historie Naturalle, Adansonia 10: 179-218.

Engler, A. 1930. Reihe Podostemales. In: Engler, A. \& Prantl, K. (eds.). Die natürlichen Pflanzenfamilien, $2^{\text {nd }}$ ed. Vol. 18a. Engelmann, Leipzig. Pp. 1-68.

Franklin, G.L. 1945. Preparation of thin sections of synthetic resins and wood-resin composites, and a new macerating method for wood. Nature 155: 51.

Jäger-Zürn, I. 2011. Neglected features of probable taxonomic value in Podostemaceae: the case of Polypleurum. Flora 206: 38-46.

Johansen, D. A. 1940. Plant microtechnique. McGrawHill, New York, 523p.

Kealhofer, L. \& Piperno, D.R. 1998. Opal phytoliths in Southeast Asian flora. Smithsonian Contributions to Botany 88: 1-39.

Kita, Y. \& Kato, M. 2001. Infrafamilial phylogeny of the aquatic angiosperm Podostemaceae inferred from the nucleotide sequences of the matK gene. Plant Biology 3: 156-163.

Koi, S. \& Kato, M. 2007. Developmental morphology of the shoot in Weddellina squamulosa and implications for shoot evolution in the Podostemaceae. Annals of Botany 99: 1121-1130.

Luque, R.; Sousa, H.C. \& Kraus, J.E. 1996. Métodos de coloração de azul de Roeser (1972) visando a substituição do azul de Astra por azul de alcião 8GS ou 8GX. Acta Botanica Brasilica 10: 199-212.

Metcalfe, C.R. \& Chalk, L. 1979. Anatomy of the Dicotyledons: systematic anatomy of the leaf and stem. $2^{\text {nd }}$ ed. Vol. 1. Oxford University Press, New York. 276p.

Neethirajan, S.; Gordon, R. \& Wang, L. 2009. Potential of silica bodies (phytoliths) for nanotechnology. Trends in Biotechnology 27: 461-467.

O’Brien, T.P; Feder, N. \& McCully, M.E. 1965. Polychromatic staining of plant cell walls by toluidine blue O. Protoplasma 49: 367-373.

Pfeifer, E.; Grob, V.; Thiv, M. \& Rutishauser, R. 2009. Stonesia ghoguei, peculiar morphology of a new Cameroonian species (Podostemaceae, Podostemoideae). Novon 19: 102-116.

Prychid, C.J.; Rudall, P.J. \& Gregory, M. 2003. Systematics and biology of silica bodies in Monocotyledons. The Botanical Review 69: 377-440.

Ruhfel, B.R.; Bittrich, V.; Bove, C.P.; Gustafsson, M.H.G.; Philbrick, C.T.; Rutishauser, R.; Xi, Z. \& Davis, C.C. 2011. Phylogeny of the clusoid clade (Malpighiales): evidence from the plastid and mitochondrial genomes. American Journal of Botany 98: 306-325.

Rutishauser, R. 1997. Structural and developmental diversity in Podostemaceae (river-weeds). Aquatic Botany 57: 29-70.

Rutishauser, R.; Grob, V. \& Pfeifer, E. 2008. Plants are used to having identity crises. In: Minelli, A. \& Fusco, G. (eds.). Key themes in evolutionary developmental biology. Cambridge University Press, Cambridge. Pp. 194 -213.

Rutishauser, R.; Pfeifer, E.; Novelo, A. \& Philbrick, C.T. 2005. Diamantina lombardii - an odd Brazilian member of the Podostemaceae. Flora 200: 245-255.

Schnell, R. 1967. Études sur l'anatomie et la morphologie des Podostemacees. Candollea 22: 157-225.

Sundae, M. 2009. Silica bodies and their systematic implications in Pteridaceae (Pteridophyta). Botanical Journal of the Linnean Society 161: 422-435.

Tippery, N.P.; Philbrick, C.T.; Bove, C.P. \& Les, D.H. 2011. Systematics and phylogeny of neotropical riverweeds (Podostemaceae: Podostemoideae). Systematic Botany 36: 105-118.

Vilella, F.S.; Becker, F.G. \& Hartz, S.M. 2002. Diet of Astyanax species (Teleostei, Characidae) in an Atlantic forest river in Southern Brazil. Brazilian Archives of Biology and Technology 45: 223-232.

Wattiez, N. \& Sternon, F. 1942. Elements de chemie vegetable. 2 ed. Masson et Cie Editeurs, Paris. 844p. 